\title{
PERILAKU SEKS PRANIKAH PADA MAHASISWA (Studi Kasus Mahasiswa UIN Suska Riau)
}

\author{
Amirah Diniaty \\ Fakultas Tarbiyah dan Ilmu Keguruan UIN Suska Riau \\ E-mail: amirah.diniaty@gmail.com
}

\begin{abstract}
Premarital sexual behavior is a sexual behavior without going through the formal process of marriage according to the law, religions and individual beliefs. It can be varied, such as feelings of attraction to the opposite sex, dating, flirting and sexual intercourse. The number of student who has sexual behavior before marriage, like icebergs on the surface of the sea, which seems just a bit, but essentially full of lumps. This is due to what she/he has done is outside monitoring of parents, faculty and the community. The results showed that the premarital sexual behavior always practiced by the respondents when they meet their partner are holding hands, kissing (dry and wet kisses) and flirting. There was a respondent who is always having sexual intercourse with his partner at least twice a week except when the patner has menstruation.
\end{abstract}

Kata Kunci : perilaku seks, pranikah, dampak, norma

\section{PENDAHULUAN}

Mahasiswa sebagai peserta didik di tingkat perguruan tinggi merupakan aset berharga bangsa. Syahrin Harahap menegaskan bahwa 
mahasiswa adalah penyandang predikat agen moral force dalam kehidupan berbangsa, bernegara, dan bermasyarakat, lebih dari komponen lain. Bahkan di era reformasi popularitas mahasiswa cenderung mengalahkan popularitas penegak moral lain seperti ulama dan para guru. Memang setelah reformasi, secara umum kepedulian mahasiswa mengalami peningkatan luar biasa sebagai penggerak perubahan (agent of change), kekuatan moral (moral force) dan kekuatan intelektual (intellectual force). ${ }^{1}$

Sebagai individu yang sedang memasuki fase dewasa awal, mahasiswa berada pada fase usia yang tidak hanya dituntut untuk sekedar lebih meningkatkan kualitas pengetahuannya, namun juga keterampilan dan kualitas pribadi sebagai bekal untuk hidup secara mandiri. Pencapaian pendidikan pada jenjang ini, diharapkan memiliki kemampuan dan wawasan yang lebih luas serta berpeluang untuk memasuki dunia kerja dan hidup di masyarakat sekaligus memiliki kesiapan untuk hidup berkeluarga.

Hal ini sesuai dengan tujuan pendidikan di UIN Suska Riau yaitu menyiapkan mahasiswa yang berakhlak mulia menjadi anggota masyarakat yang memiliki kemampuan dan keunggulan akademik dan profesional yang dapat menerapkan, mengembangkan, dan mengaplikasikan ilmu agama Islam, teknologi, seni, dan ilmu lain yang terkait. Pencapaian tujuan tersebut sungguh penuh dengan tantangan karena kehidupan masyarakat di era globalisasi yang semakin kompleks. ${ }^{2}$

Seiring dengan tujuan pendidikan bagi mahasiswa tersebut, ditinjau dari tugas perkembangan yang sedang dihadapi pada fase usia dewasa awal, maka salah satu tugas perkembangan yang sedang dihadapi mahasiswa adalah "mempersiapkan pernikahan dan hidup berkeluarga."3 Konsekuensinya, diharapkan para mahasiswa mampu menyelesaikan tugas perkembangannya dengan secara efektif dan optimal, baik dalam tugas akademiknya sebagai calon cendikia, juga dalam mempersiapkan karir dan pernikahan dalam hidup berkeluarga. Tantangan berat saat ini bagi mahasiswa, khususnya yang menyelesaikan studi pada strata 1 (S1) yang berusia antara 17-25 tahun, dalam pencapaian tugas perkembangannya adalah fenomena yang terjadi saat ini; yaitu perilaku seks pranikah.

Mahasiswa, melakukan berbagai macam perilaku seksual beresiko yang terdiri atas tahapan-tahapan tertentu, yaitu dimulai dari berpegangan tangan, cium kering, cium basah, berpelukan, memegang atau meraba bagian sensitif, petting, oral sex, dan bersenggama (sexua intercourse). Perilaku seksual pranikah pada remaja ini pada akhirnya 
dapat mengakibatkan berbagai dampak yang merugikan remaja itu sendiri. ${ }^{4}$

Survey awal dari wawancara dengan beberapa dosen dan pegawai di fakultas yang ada di UIN Suska Riau, terungkap bahwa tingkat putus kuliah pada mahasiswa juga sangat mencemaskan, karena kasus seks pranikah ini. Kasus yang terjadi di Fakultas Tarbiyah dan keguruan UIN Suska Riau sejak Tahun Akademik 2010 hingga sekarang tercatat ada 2 kasus mahasiswa yang tertangkap melakukan seks pranikah dan diskor (berhenti sementara kuliah). Fakultas Dakwah ada 3 kasus, sementara data dari fakultas lain belum tercatat. Kasus tersebut ibarat gunung es dipermukaan laut, dimana yang diketahui hanya sedikit, dan mungkin saja belum menyentuh ke akarnya bahwa diluar pemantauan orang tua, dosen dan masyarakat mahasiswa melakukan seks pranikah tersebut. Apalagi mahasiswa yang kebanyakan berada jauh dari pengawasan orang tua karena indekos (tinggal dirumah kontrakan yang tidak ada ibu/bapak pemilik rumah sewaan), maka perilaku seks pranikah ini menjadi sangat riskan terjadi.

Survey awal yang penulis lakukan dengan mengobservasi dan mewawancarai mahasiswa terungkap bahwa sebahagian besar mereka telah menjalin hubungan serius dengan lawan jenis (pacaran). Perilaku mereka dengan lawan jenis ada yang ditunjukkan langsung tidak sesuai dengan norma etika, susila, dan agama, seperti duduk berduaan di pojok ruang kuliah saat dosen tidak ada, berfoto mesra (terlihat dari tampilan layar laptopnya) dan informasi dari pengamat lain yang mengatakan bahwa ketika membayar SPP ke sebuah bank rekanan UIN Suska Riau, rata-rata mahasiswi itu didampingi oleh pasangannya.

Berdasarkan fenomena yang ada pada latar belakang diatas, maka masalah umum penelitian ini adalah "Bagaimana perilaku seks pranikah pada mahasiswa dan upaya mencegah serta mengatasinya?". Secara khusus rumusan masalah pada penelitian ini adalah sebagai berikut; (1)Apa bentuk perilaku seks pranikah pada mahasiswa? (2) Apa faktor yang memicu perilaku seks pranikah pada mahasiswa? (3) Bagaimana dampak/akibat dari perilaku seks pranikah pada mahasiswa tersebut? (4) Bagaimana mahasiswa mencegah terjadinya perilaku seks pranikah?

Penelitian ini berbentuk penelitian deskriptif kualitatif, yaitu mendeskripsikan secara naratif dan mendalam tentang perilaku seks pranikah pada mahasiswa UIN Suska Riau yang menjadi objek penelitian. Masalah penelitian berasal dari kondisi mahasiswa UIN Suska Riau yang diperkirakan memiliki gejala tingkah laku seks pranikah yang diperoleh dari hasil observasi dan wawancara assesment awal. Subjek utama 
penelitian adalah mahasiswa di lingkungan UIN Suska Riau yang dari assesment awal melalui wawancara dan observasi diketahui menunjukkan perilaku seks pranikah. Mahasiswa tersebut sebagai subjek utama penelitian dijadikan informan kunci. Penyebaran informan (mahasiswa) ada di fakultas Tarbiyah dan Keguruan, Syariah dan Ilmu Hukum, Dakwah dan Ilmu Komunikasi, Psikologi, Ekonomi dan Sosial, Pertanian dan Peternakan. Pengambilan responden sebagai subjek penelitian dari fakultas-fakultas tersebut dengan teknik snow ball dan purposive. Snow ball dimaksud adalah pengambilan responden dengan tidak ditentukan langsung, mengelinding sesuai dengan informasi tentang mahasiswa mana yang menunjukkan berperilaku seks pranikah. Purposive dimaksud responden mewakili masing-masing fakultas dan menunjukkan perilaku seks pranikah. Berdasarkan teknik tersebut jumlah responden yang diperoleh adalah 5 (lima) orang.

Data didapatkan dari lima orang mahasiswa melalui bantuan dua orang mahasiswa yang diminta melacak dan mencari informasi tentang perilaku seks pranikah yang dilakukan oleh mahasiswa tersebut. Kedua mahasiswa tersebut mendapatkan responden melalui proses hubungan akrab yang telah mereka bentuk dengan responden. Responden tidak diberitahu bahwa dia adalah objek dari penelitian sehingga data yang dicatat dari wawancara yang dilakukan lebih objektif. Alat dan teknik pengumpulan data utama yang digunakan dalam penelitian adalah wawancara. Ada dua bentuk wawancara yang dilakukan yaitu wawancara langsung yaitu peneliti yang mewawancarai responden dan wawancara tidak langsung (melalui mahasiswa interviwer) terhadap responden yang menjadi subjek penelitian. Wawancara dilakukan untuk mengumpulkan data tentang; bentuk perilaku seks pranikah pada mahasiswa, Faktor yang memicu perilaku seks pranikah pada mahasiswa, dampak/akibat dari perilaku seks pranikah pada mahasiswa, upaya mahasiswa mencegah terjadinya perilaku seks pranikah, dan upaya mahasiswa mengatasi perilaku seks pranikah yang telah terjadi dan tidak terulang lagi.

\section{PEMBAHASAN}

\section{Seks Bebas dalam Pandangan Islam}

Dalam Islam, seks bebas jelas-jelas diharamkan. Diantara tujuan diturunkannya syariat Islam adalah menjaga kehormatan dan keturunan, karena itu syariat Islam mengharamkan seks bebas (zina), Allah Subhanahu wata'ala berfirman: "Dan janganlah kamu mendekati zina, 
sesungguhnya zina itu sesuatu perbuatan yang keji dan suatu jalan yang buruk" (Al Isra' : 32)

Bahkan syariat Islam menutup segala pintu dan sarana yang mengundang perbuatan zina, yakni dengan mewajibkan hijab, menundukkan pandangan, juga dengan melarang khalwat (berduaan di tempat yang sepi) dengan lawan jenis bukan mahram dan sebagainya.

Islam tegas menyebutkan hukuman bagi pezina muhshan (yang telah beristri) adalah hukuman yang paling berat dan menghinakan. Yaitu dengan merajam (melemparnya dengan batu hingga mati). Hukuman ini ditimpakan agar pelaku merasakan akibat dari perbuatannya yang keji, juga agar setiap anggota tubuhnya kesakitan, sebagai imbalan dari menikmati yang haram.

Adapun pezina yang belum pernah melakukan hubungan seks melalui nikah yang sah, maka ia dicambuk sebanyak seratus kali. Suatu bilangan yang paling banyak dalam hukuman cambuk yang dikenal dalam Islam. Hukuman ini harus disaksikan sekelompok kaum mukminin. Suatu bukti betapa hukuman ini amat dihinakan dan dipermalukan. Tidak hanya itu, pezina tersebut selanjutnya harus dibuang dan diasingkan dari tempat ia melakukan perzinaan, selama satu tahun penuh.

Adapun siksaan para pezina -baik laki-laki maupun perempuandi alam barzakh adalah ditempatkan di dapur api yang atasnya sempit dan bawahnya luas. Dari bawah tempat tersebut, api dinyalakan. Sedang mereka berada didalamnya dalam keadaan talanjang. Jika dinyalakan mereka teriak, malolong-lolong dan memanjat keatas hingga hampirhampir saja mereka bisa keluar, tapi bila api dipadamkan, mereka kembali lagi ke tempatnya semula (di bawah) lalu api kembali lagi dinyalakan. Demikian terus berlangsung hingga datangnya hari kiamat. ${ }^{5}$

Keadaannya akan lebih buruk lagi jika laki-laki tersebut sudah tua tapi terus saja berbuat zina, padahal kematian hampir menjemputnya, tetapi Allah Tabaroka wata'ala masih memberinya tenggang waktu.

Dalam hadits marfu' dari Abu Hurairah Radhiallahu'anhu disebutkan :

“Tiga (jenis manusia) yang tidak akan diajak bicara oleh Allah pada hari kiamat, juga Allah tidak akan menyucikan mereka dan tidak pula memandang kepada mereka, sedang bagi mereka siksa yang pedih, yaitu laki-laki tua yang suka berzina, seorang raja pendusta, dan orang miskin yang sombong". (HR Muslim : 1/102-103).

Di zaman sekarang, segala pintu kemaksiatan terbuka lebar. Setan mempermudah jalan (menuju kemaksiatan) dengan tipu dayanya dan 
tipu daya pengikutnya. Para tukang maksiat dan ahli kemungkaran membeo setan. Pergaulan bebas antara laki-laki dengan perempuan merajalela, tak terkecuali di lembaga pendidikan yang nota benenya Islam.

\section{Penyebab Perilaku Seks Pranikah pada Remaja dan Dampaknya}

Perilaku seksual adalah segala tingkah laku yang didorong oleh hasrat seksual baik yang dilakukan sendiri, dengan lawan jenis maupun sesama jenis tanpa adanya ikatan pernikahan menurut agama. ${ }^{6}$ Menurut Stuart dan Sundeen, ${ }^{7}$ perilaku seksual yang sehat dan adaptif dilakukan ditempat pribadi dalam ikatan yang sah menurut hukum. Sedangkan perilaku seksual pranikah merupakan perilaku seksual yang dilakukan tanpa melalui proses pernikahan yang resmi menurut hukum maupun menurut agama dan kepercayaan masing-masing. ${ }^{8}$

Seks pra nikah tidak bisa dilepaskan pemahamannya dengan seks bebas atau pergaulan bebas. Fenomena pergaulan bebas di kalangan mahasiswa sesungguhnya telah berlangsung cukup lama, yaitu sekitar awal dekade 1990an. Sampai saat ini, pergaulan remaja di Indonesia semakin mengkhawatirkan. Perilaku seks bebas (zina) pra nikah tidak hanya dilakukan kaum dewasa, namun sudah merambah di kalangan pelajar bahkan mulai tingkat SD (suaramerdeka.com-1 April 2012). Pondok Pesantren At-Tauhid, Parakan, kabupaten Temanggung, melakukan penelitian tentang fenomena seks bebas di kalangan pelajar. Hasilnya, 7,5\% pelajar SD, 65\% pelajar SMP dan 80\% pelajar SMA atau sederajat, mengaku melakukan seks bebas. Survei yang dilakukan di 33 provinsi pada pertengahan tahun 2008 melaporkan bahwa 63\% remaja di Indonesia usia sekolah SMP dan SMA melakukan seks bebas dan 21\% diantaranya melakukan aborsi. ${ }^{9}$

Menurut penelitian yang dilakukan oleh Suryoputro tentang faktorfaktor yang mempengaruhi perilaku seksual remaja di Jawa Tengah adalah:10 (a) faktor internal, yaitu pengetahuan, aspek-aspek kesehatan reproduksi, sikap terhadap layanan kesehatan seksual dan reproduksi, perilaku, kerentanan yang dirasakan terhadap resiko, kesehatan reproduksi, gaya hidup, pengendalian diri, aktifitas sosial, rasa percaya diri, usia, agama, dan status perkawinan, (b) faktor eksternal, yaitu kontak dengan sumber-sumber informasi, keluarga, sosial-budaya, nilai dan norma sebagai pendukung sosial untuk perilaku tertentu.

Seringkali remaja merasa bahwa orang tuanya menolak membicarakan masalah seks pranikah sehingga mereka kemudian mencari alternatif sumber informasi lain seperti teman atau media 
massa. ${ }^{11}$ Beberapa kajian menunjukkan bahwa remaja sangat membutuhkan informasi mengenai persoalan seksual dan reproduksi. Remaja seringkali memperoleh informasi yang tidak akurat mengenai seks dari teman-teman mereka, bukan dari petugas kesehatan, guru atau orang tua.

Faktor lingkungan yang sangat berpengaruh terhadap perilaku reproduksi remaja diantaranya adalah faktor keluarga. Remaja yang melakukan hubungan seksual sebelum menikah banyak diantara berasal dari keluarga yang bercerai atau pernah cerai, keluarga dengan banyak konflik dan perpecahan. ${ }^{12}$ Hubungan orang-tua yang harmonis akan menumbuhkan kehidupan emosional yang optimal terhadap perkembangan kepribadian anak sebaliknya. Orang tua yang sering bertengkar akan menghambat komunikasi dalam keluarga, dan anak akan "melarikan diri" dari keluarga. Keluarga yang tidak lengkap misalnya karena perceraian, kematian, dan keluarga dengan keadaan ekonomi yang kurang, dapat mempengaruhi perkembangan jiwa anak. ${ }^{13}$ Faktor-faktor yang mempengaruhi perilaku seksual pranikah pada remaja paling tinggi hubungan antara orang tua dengan remaja, diikuti karena tekanan teman sebaya, religiusitas, dan eksposur media pornografi. ${ }^{14}$

Beberapa faktor lain yang mempengaruhi perilaku seksual pada remaja adalah perubahan hormonal, penundaan usia perkawinan, penyebaran informasi melalui media massa, tabu-larangan, norma-norma di masyarakat, serta pergaulan yang makin bebas antara laki-laki dan perempuan. ${ }^{15}$

Perilaku seksual pranikah dapat menimbulkan berbagai dampak negatif pada remaja, antara lain sebagai berikut:16 (a) Dampak psikologis; diantaranya perasaan marah, takut, cemas, depresi, rendah diri, bersalah dan berdosa, (b) Dampak Fisiologis; dapat menimbulkan kehamilan tidak diinginkan dan aborsi, (c). Dampak sosial; antara lain dikucilkan, putus kuliah pada remaja perempuan yang hamil, dan perubahan peran menjadi ibu. Belum lagi tekanan dari masyarakat yang mencela dan menolak keadaan tersebut (d) Dampak fisik; seperti berkembangnya penyakit menular seksual di kalangan remaja, dengan frekuensi penderita penyakit menular seksual (PMS) yang tertinggi antara usia 15-24 tahun. Infeksi penyakit menular seksual dapat menyebabkan kemandulan dan rasa sakit kronis serta meningkatkan risiko terkena PMS dan HIV/AIDS.

Terkait dengan itu, sesuai dengan data meningkatnya kasus penularan penyakit seksual, UNESCO mengembangkan pedoman baru pendidikan seks bagi remaja. Salah satu faktor penyebab tingginya tingkat pergaulan bebas di kalangan remaja adalah kemudahan mengakses 
cybersex oleh semua kalangan, termasuk remaja. Mark B. Kastleman, pakar psikologi menyatakan bahwa situs porno diakses lebih dari 200 juta orang setiap harinya. Kastlemen mengibaratkan pornografi sebagai the drug of new millenium. Pornografi yang ditonton 31 sampai 36 kali akan mengakibatkan ketergantungan. Anak akan menjadi the future market pasar masa depan, karena anak akan kecanduan. Dampaknya, pengetahuan anak tentang seks akan lebih hebat dari orang tuanya. ${ }^{17}$

Lebih jauh dijelaskan dalam disertasi Mutimmatul Saidah, hasil survey perusahaan kontrasepsi pada tahun 2005 pada sebagian kota besar di Indonesia dari Sabang hingga Merauke yang dikemukakan Direktur Remaja dan Perlindungan Hak-hak Reproduksi Badan Koordinasi Keluarga Berencana Nasional $(\mathrm{BKKN})$, M. Masri Muadz secara menyatakan bahwa sekitar $40 \%$ s.d. $45 \%$ remaja berusia 14 s.d. 24 tahun, telah berhubungan seks pranikah. Hasil tersebut menunjukkan $60 \%$ remaja mengaku tidak mengetahui informasi tentang penyakit menular seksual (PMS). ${ }^{18}$ Selain itu, didukung oleh data BKKBN yang menunjukkan bahwa $60 \%$ remaja sudah ingin mendapatkan pelayanan keluarga berencana (KB). Padahal, sesuai aturan, alat kontrasepsi hanya boleh diberikan kepada pasangan yang menikah. ${ }^{19}$

Data dari Unesco menyebutkan bahwa lebih dari 5 juta anak muda hidup dengan HIV. Sebanyak 45\% terjadi pada usia 15 s.d. 24 tahun. Data lain menunjukkan bahwa setiap tahun sedikitnya 111 juta kasus baru tentang penularan penyakit lewat hubungan seksual. Kasus tersebut terjadi pada usia 10s.d. 24 tahun. Sebanyak 4,4 juta anak perempuan berusia 15 s.d. 19 tahun melakukan aborsi yang tidak aman. Selain itu, sekitar 10 persen kelahiran di dunia terjadi di kalangan remaja perempuan yang rentan mengalami kematian saat melahirkan. ${ }^{20}$

Dari temuan di atas, jelas sekali dampak negatif pergaulan bebas/sex pranikah menimbulkan banyak akibat bagi mahasiswa yang sangat diharapkan sebagai aset bangsa, ditambah lagi masa depan mereka ketika akan membina rumah tangga. Akibat secara fisik seperti; penyakit HIV/ AIDS, aborsi yang bisa menyebabkan hilangnya nyawa.

Akibat dari perilaku seks pranikah, yaitu pernikahan di usia muda yang terjadi karena terpaksa setelah ketahuan berzina, dapat menyebabkan kehidupan dalam rumah tangga tidak harmonis dan bahagia. Belum lagi tekanan dari masyarakat yang mencela dan menolak keadaan tersebut. Resiko yang lain adalah terganggunya kesehatan yang bersangkutan, resiko kelainan janin dan tingkat kematian bayi yang tinggi. 


\section{HASIL PENELITIAN}

\section{Bentuk Perilaku Seks Pranikah pada Mahasiswa}

Penelitian yang dilakukan terhadap lima orang mahasiswa sebagai objek menunjukkan bahwa bentuk perilaku seks pranikah mulai dari berpengangan tangan sebagai suatu hal biasa dan dilakukan setiap kali bertemu, mencium pasangan (ciuman kering dan basah) masih hal biasa dilakukan bahkan ada yang melakukan setiap kali pertemua dengan pasangan. Perilaku berpelukan dengan pasangan, ada 1 responden yang tidak melakukan. Namun 4 responden lainnya melakukan perilaku berpelukan dengan pasangan minimal $2 \times$ dalam sebulan, bahkan ada yang 2 x dalam seminggu.

Bentuk perilaku seks pranikah lebih jauh yang dilakukan oleh responden yaitu 4 responden memegang/meraba bagian sensitif pasangannya minimal $1 \times$ selama berpacaran dan paling sering minimal 2 $\mathrm{x}$ dalam seminggu. Meraba alat kelamin pasangan hanya dilakukan 1 responden, dan tidak ada responden yang melakukan oral seks. Lebih lanjut, perilaku seks pranikah yaitu senggama hanya dilakukan oleh 1 responden yaitu DG minimal $1 \times$ seminggu kecuali saat pacar sedang haid). Perbuatan ini dilakukan di tempat kost atau hotel. Biasanya pacar DG yang mendatanginya karena memiliki mobil dan mengajak DG keluar. Setiap akan melakukan senggama mereka memulai dengan menonton bersama, vidio porno di laptop DG/pacar. Untuk memudahkan gambaran bentuk perilaku seks pranikah tersebut dijelaskan dalam tabel berikut :

Tabel 1

Bentuk perilaku seks pranikah pada mahasiswa

\begin{tabular}{|c|c|c|c|c|c|c|}
\hline \multirow[b]{2}{*}{$\begin{array}{l}\mathrm{N} \\
\mathrm{O}\end{array}$} & \multirow{2}{*}{$\begin{array}{c}\text { Bentuk } \\
\text { Perilaku Seks } \\
\text { Pranikah }\end{array}$} & \multicolumn{5}{|c|}{ Responden } \\
\hline & & $\begin{array}{l}\text { AF } \\
\text { (laki- } \\
\text { laki) }\end{array}$ & $\begin{array}{l}\text { DR } \\
\text { (laki- } \\
\text { laki) }\end{array}$ & $\begin{array}{c}\mathrm{KH} \\
\text { (perempua } \\
\mathrm{n})\end{array}$ & $\begin{array}{c}\text { BA } \\
\text { (laki-laki) }\end{array}$ & $\begin{array}{l}\text { WG } \\
\text { (laki- } \\
\text { laki) }\end{array}$ \\
\hline 1 & $\begin{array}{l}\text { Berpegangan } \\
\text { tangan, } \\
\text { dilakukan } \\
\text { dalam minggu/ } \\
\text { bulan }\end{array}$ & $\begin{array}{l}\text { Ya, saat } \\
\text { menyebe- } \\
\text { rang jalan } \\
1 \mathrm{x} \\
\text { seminggu }\end{array}$ & $\begin{array}{l}\text { Ya, tiap } \\
\text { jumpa } \\
\text { minimal } \\
\quad 2 x \\
\text { seminggu }\end{array}$ & $\begin{array}{l}\text { Ya, tiap } \\
\text { jumpa } \\
\text { minimal } \\
2 x \\
\text { seminggu }\end{array}$ & \begin{tabular}{l}
\multicolumn{1}{c}{ Ya, } \\
jumpa tak \\
pasti \\
waktu \\
min. $2 x$ \\
seminggu
\end{tabular} & \begin{tabular}{l}
\multicolumn{1}{c}{ Ya, } \\
jumpa \\
tak pasti \\
waktu \\
min. $2 x$ \\
semingg \\
u
\end{tabular} \\
\hline 2 & $\begin{array}{l}\text { Cium kering, } \\
\text { dilakukan } \\
\text { dalam minggu }\end{array}$ & $\begin{array}{c}\text { Ya, saat } \\
\text { dia ulang } \\
\text { tahun }(1\end{array}$ & $\begin{array}{l}\text { Ya, saat } \\
\text { jumpa } \\
\text { (min. } 2 x\end{array}$ & $\begin{array}{l}\text { Ya, saat } \\
\text { jumpa } \\
\text { (min. } 2 x\end{array}$ & $\begin{array}{l}\text { Ya, saat } \\
\text { jumpa } \\
\text { (min. } 2 x\end{array}$ & $\begin{array}{l}\text { Ya, saat } \\
\text { jumpa } \\
\text { (min. } 2\end{array}$ \\
\hline
\end{tabular}




\begin{tabular}{|c|c|c|c|c|c|c|}
\hline & /bulan & $\begin{array}{c}x \\
\text { setahun) }\end{array}$ & $\begin{array}{c}\text { seminggu } \\
\text { ) }\end{array}$ & seminggu) & seminggu & $\begin{array}{c}x \\
\text { semingg } \\
u\end{array}$ \\
\hline 3 & $\begin{array}{l}\text { Cium basah, } \\
\text { dilakukan } \\
\text { dalam minggu } \\
\text { / bulan }\end{array}$ & Tidak & $\begin{array}{l}\text { Ya, } 2 \text { x } \\
\text { dalam } \\
\text { sebulan }\end{array}$ & $\begin{array}{l}\text { Ya, } 2 x \\
\text { dalam } \\
\text { sebulan }\end{array}$ & $\begin{array}{l}\text { Ya, } 2 x \\
\text { dalam } \\
\text { sebulan }\end{array}$ & $\begin{array}{c}\text { Ya, saat } \\
\text { jumpa } \\
\text { min. } 2 x \\
\text { semingg } \\
u\end{array}$ \\
\hline 4. & $\begin{array}{l}\text { berpelukan, } \\
\text { dilakukan } \\
\text { dalam minggu } \\
\text { / bulan }\end{array}$ & Tidak & $\begin{array}{l}\text { Ya, } 2 x \\
\text { dalam } \\
\text { sebulan }\end{array}$ & $\begin{array}{l}\text { Ya, } 2 x \\
\text { dalam } \\
\text { sebulan }\end{array}$ & $\begin{array}{c}\text { Ya. } 2 x \\
\text { dalam } \\
\text { seminggu }\end{array}$ & $\begin{array}{c}\text { Ya. } \\
\text { minimal } \\
2 x \\
\text { semingg } \\
\mathrm{u}\end{array}$ \\
\hline 5 & $\begin{array}{l}\text { Memegang/ } \\
\text { meraba bagian } \\
\text { sensitif, } \\
\text { dilakukan } \\
\text { dalam minggu } \\
\text { /bulan }\end{array}$ & Tidak & $\begin{array}{l}\text { Ya, satu } \\
\text { kali } \\
\text { selama } \\
\text { pacaran }\end{array}$ & $\begin{array}{c}\text { Ya, satu } \\
\text { kali selama } \\
\text { pacaran }\end{array}$ & $\begin{array}{l}\text { Ya, } 3 x \\
\text { selama } \\
\text { pacaran }\end{array}$ & $\begin{array}{c}\text { Ya, } \\
\text { minimal } \\
2 x \\
\text { dalam } \\
\text { semingg } \\
u\end{array}$ \\
\hline 6 & $\begin{array}{l}\text { petting/meraba } \\
\text { alat kelamin, } \\
\text { dilakukan dlm } \\
\text { minggu/bulan }\end{array}$ & Tidak & Tidak & Tidak & Tidak & $\begin{array}{c}\text { Ya, } \\
\text { minimal } \\
2 x \\
\text { dalam } \\
\text { semingg } \\
\mathrm{u}\end{array}$ \\
\hline 7 & $\begin{array}{l}\text { Oral sex, dlm } \\
\text { minggu/bulan }\end{array}$ & Tidak & Tidak & Tidak & tidak & Tidak \\
\hline 8 & $\begin{array}{l}\text { bersenggama } \\
\text { dilakukan } \\
\text { dalam } \\
\text { minggu/bulan }\end{array}$ & Tidak & Tidak & Tidak & Tidak & $\begin{array}{c}\text { Ya, min. } \\
1 x \\
\text { semingg } \\
u \\
\text { kecuali } \\
\text { jika } \\
\text { haid }\end{array}$ \\
\hline
\end{tabular}

Hasil penelitian ini menunjukkan bentuk perilaku seks pranikah yang dilakukan mahasiswa mulai dari memegang tangan sampai melakukan hubungan senggama. Semua perilaku seks tersebut dilakukan seharusnya pada saat pasangan telah menikah. Namun mereka belum menikah, sudah melakukan hal itu. Perbuatan ini menjadi tidak seharusnya dilakukan karena status mereka yang belum menikah, dan sangat dilarang oleh agama, adat dan susila. 


\section{Faktor yang Memicu Perilaku Seks Pranikah pada Mahasiswa}

Faktor pemicu prilaku seks pranikah pada responden dibedakan kepada dua aspek, yaitu factor internal dan factor eksternal. Hasil penelitian menunjukkan bahwa faktor internal yang memicu mahasiswa melakukan perilaku seks pranikah antara lain adalah faktor usia dan gaya hidup, factor pengetahuan tentang aspek-aspek kesehatan reproduksi, sikap terhadap layanan kesehatan seksual dan reproduksi, rasa percaya diri, keyakinan bahwa dirinya menarik/ gagah, dan kebutuhan ekonomi yang bergantung pada pasangan.

Faktor eksternal adalah tekanan teman sebaya, pengaruh temanteman (sering ditantang teman supaya melakukan itu), dan eksposur media pornografi/kontak dengan sumber-sumber informasi. Untuk memudahkan penjelasan faktor yang mempengaruhi kelima responden dapat dilihat dalam tabel berikut :

Tabel 2

Faktor yang memicu perilaku seks pranikah pada mahasiswa

\begin{tabular}{|c|c|c|c|c|c|c|}
\hline \multirow[b]{2}{*}{ No } & \multirow{2}{*}{$\begin{array}{c}\text { Faktor } \\
\text { yang } \\
\text { memicu }\end{array}$} & \multicolumn{5}{|c|}{ Responden } \\
\hline & & $\mathrm{AF}$ & DR & $\mathrm{KH}$ & $\mathrm{BA}$ & WG \\
\hline 1 & Internal & $\begin{array}{l}\text { Faktor usia } \\
\text { dan gaya } \\
\text { hidup }\end{array}$ & $\begin{array}{l}\text {-Pengeta- } \\
\text { huan ttg } \\
\text { aspek2 } \\
\text { kesehatan } \\
\text { reproduk si, } \\
\text { - sikap } \\
\text { terhadap } \\
\text { layanan } \\
\text { kesehatan } \\
\text { seksual dan } \\
\text { repro-duksi } \\
\text {-Usia }\end{array}$ & $\begin{array}{l}\text {-gaya } \\
\text { hidup } \\
\text { - usia }\end{array}$ & $\begin{array}{l}\text {-rasa } \\
\text { percaya } \\
\text { diri. } \\
\text { Merasa } \\
\text { cocok dan } \\
\text { wajar } \\
\text { melakukan } \\
\text { perilaku } \\
\text { tersebut } \\
\text {-keyakinan } \\
\text { bahwa } \\
\text { dirinya } \\
\text { menarik/ } \\
\text { gagah. } \\
\text { - usia }\end{array}$ & $\begin{array}{l}\quad \text { gaya } \\
\text { hidup } \\
\text { usia } \\
\text { - kebutu- } \\
\text { han } \\
\text { ekonomi } \\
\text { yang ber- } \\
\text { gantung } \\
\text { pada } \\
\text { pasang- } \\
\text { an }\end{array}$ \\
\hline 2 & Eksternal & $\begin{array}{c}\text {-eksposur } \\
\text { media } \\
\text { pornografi/ } \\
\text { kontak } \\
\text { dengan } \\
\text { sumber } \\
\text { informasi }\end{array}$ & $\begin{array}{c}\text {-eksposur } \\
\text { media } \\
\text { pornografi/ } \\
\text { kontak } \\
\text { dengan } \\
\text { sumber- } \\
\text { sumber }\end{array}$ & $\begin{array}{l}\text {-eksposur } \\
\text { media } \\
\text { pornografi } \\
\text { / kontak } \\
\text { dengan } \\
\text { sumber } \\
\text { informasi }\end{array}$ & $\begin{array}{l}\text {-tekanan } \\
\text { teman } \\
\text { sebaya. } \\
\text { teman- } \\
\text { teman (BA } \\
\text { sering } \\
\text { ditantang }\end{array}$ & $\begin{array}{l}\text { - } \\
\text { tekanan } \\
\text { teman } \\
\text { sebaya. } \\
\text { teman- } \\
\text { teman } \\
\text { (WG }\end{array}$ \\
\hline
\end{tabular}




\begin{tabular}{|c|c|c|}
\hline+2 & $\begin{array}{l}\text { teman agar } \\
\text { melakukan } \\
\text {-eksposur } \\
\text { media } \\
\text { pornografi } \\
\text { / kontak } \\
\text { dengan } \\
\text { sumber } \\
\text { informasi }\end{array}$ & $\begin{array}{l}\text { sering } \\
\text { ditantan } \\
\text { g agar } \\
\text { melaku- } \\
\text { kan. } \\
\text { - } \\
\text { eksposur } \\
\text { media } \\
\text { pornogra } \\
\text { fi/kontak } \\
\text { dengan } \\
\text { sumber } \\
\text { informasi }\end{array}$ \\
\hline
\end{tabular}

Perilaku seks pranikah yang dilarang agama, adat, dan susila, ternyata tidak terjadi begitu saja. Hasil penelitian ini menunjukkan factor yang dominan adalah internal yaitu gaya hidup saat ini dimana hubungan seks pranikah sudah dianggap sesuatu yang wajar bahkan menjadi standar social diantara teman sebaya. Konsep diri yang salah bahwa mampu melakukan hubungan seks pranikah adalah hebat., perlu dikaji ulang oleh remaja/dewasa awal.

Faktor eksternal yaitu eksposur media video porno adalah factor dominant lainnya. Hal ini juga menjadi persoalan yang harus diwaspadai. Vidio porno yang mudah di akses oleh orang dewasa awal adalah racun yang dapat menggerogoti moral dan akhlak individu.

\section{Dampak dari Perilaku Seks Pranikah pada Mahasiswa}

Dampak dari perilaku seks pranikah dapat dilihat dari dampak fisik yaitu mahasiswa menjadi mudah lelah, lesu, nyeri sendi, lutut menjadi lemas. Sementara dampak fisiologis adalah mudah ejakulasi dini dan sering melakukan onani.

Dampak psikologis yang dirasakan mahasiswa adalah mereka merasa bersalah melakukan perbuatan terlarang, dan melamun/berkhayal untuk bisa melakukan hubungan seks dengan pasangan. Dampak sosial yang terjadi adalah merasa tidak percaya diri, dan sebaliknya secara sosial ada yang dianggap hebat oleh lingkungan sebaya. Lingkungan dewasa khususnya orang tua mereka tidak mengetahui sama sekali perbuatan mereka.

Hasil penelitian ini menunjukkan bahwa ternyata perilaku seks pranikah berdampak negatif pada pelakunya. Seharusnya ini menjadi pelajaran bagi individu lainnya. 


\section{Upaya Mahasiswa Mencegah Perilaku Seks Pranikah}

Responden penelitian ini menyatakan sesungguhnya mahasiswa ingin mencegah perilaku seks pranikah agar tidak terjadi lagi, walaupun melakukan hubungan seks pranikah. Upaya mereka adalah menahan birahi mengingat tanggung jawab sebagai anak tertua.

Pasangan juga marah dan melarang melakukan tindakan yang mengarah pada perilaku seks pranikah yang lebih jauh dari ciuman. Hal ini dapat mencegah perilaku seks pranikah.

Upaya lain adalah memilih tempat dan waktu untuk bertemu dengan pacar tidak di tempat yang sangat sepi dan malam hari yang sangat larut (lewat dari jam 10). Selain itu berusaha menjaga jarak dari pasangan.

Upaya lain adalah mengingat Tuhan dan berencana akan memilih pasangan tetap perempuan muslimah yang taat. Jadi pasangan yang memberikan peluang dan kesempatan akan sulit membuat responden untuk mencegah perilaku seks pranikah. Oleh sebab itu, terjadinya hubungan seks pranikah dapat dicegah dengan kuatnya salah satu dari pasangan, atau kedua belah pihak, dalam menahan diri untuk tidak melakukannya.

Hasil penelitian juga menunjukkan bahwa jika pasangan mereka, yaitu pihak perempuan, membentengi diri, tidak memberikan peluang melakukan perilaku seks pranikah, maka niat mereka (mahasiswa/pria) tidak akan bisa diwujudkan. Kesempatan dan niat melakukan perilaku seks pranikah akan musnah kalau perempuan menyatakan tidak dan tidak menstimulus mereka. Ini menjadi penting untuk dipahami oleh semua mahasiswi bahwa membina hubungan dengan lawan jenis dalam rangka mengembangkan diri harus betul-betul berprinsip dan mampu menjaga diri dari perilaku yang memancing terjadinya perilaku seks pranikah tersebut.

Perilaku mahasiswi sebagai muslimah yang harus mampu menjaga kesucian diri, dengan tegas mengatakan tidak terhadap perilaku seks pranikah perlu dikembangkan. Keterampilan membela diri dan menjauhi kesempatan rawan seperti keluar pada malam hari dan pergi ketempat yang sepi perlu dimiliki oleh mahasiswi. Tidak salah ungkapan bahwa perempuan adalah tiangnya negara. Jika perempuan baik, maka baiklah negera itu. Jika perempuan rapuh dan lemah maka hancurlah negara itu.

\section{SIMPULAN DAN REKOMENDASI}


Hasil penelitian ini menunjukkan bahwa perilaku seks pranikah yang dilakukan mahasiswa sudah melewati batas yang tidak patut dilakukan. Untuk itu perlu kontrol dari lingkungan akademik di kampus seperti Satuan Keamanan (SATPAM) melihat jika ada gelagat perilaku yang tidak wajar yang ditunjukkan oleh mahasiswa, umpamanya berduaduaan di pojok kampus sampai menjelang malam atau malam hari.

Mengingat perilaku seks pranikah ini banyak dilakukan di luar kampus seperti di ditempat kost, maka lingkungan masyarakat mulai dari RT, RW, Lurah perlu diajak oleh kampus untuk bekerjasama dalam mengontrol perilaku mahasiswa.

Faktor eksternal seperti vidio porno yang dapat memicu perilaku seks pranikah perlu disikapi dengan bijak oleh mahasiswa sebagai pemakai teknologi. Teknologi komputer dan internet tidak bisa ditahan bahkan dibutuhkan untuk memperlancar kegiatan akademik di perkuliahan. Namun perlu ada sortir dan benteng untuk tidak menggunakan/melihat vidio porno tersebut. Sosialisasi tentang hal ini perlu dilakukan oleh pihak UIN Suska pada mahasiswa.

Dampak negatif perilaku seks pranikah, juga harus disosialisasikan dalam bentuk seminar, audiensi dan sebagainya pada mahasiswa. Dan upaya mencegah perilaku seks seharusnya diperbanyak dari sisi mahasiswa itu sendiri, dan orang tua dalam hal ini disarankan tetap memberikan pengawasan anaknya walaupun sudah berada pada dewasa awal.

\section{Endnotes:}

${ }^{1}$ Syahrin Harahap. 2005. Penegakan Moral Akademik di dalam dan diluar kampus. Jakarta: PT. RajaGrafindo Persada.

2 Buku Panduan dan Informasi Akademik 2008-2009 UIN Suska Riau

3 Elizabeth B.Harlock (1991). Psikologi Perkembangan (edisi kelima). Erlangga: Jakarta

4 Irawati dan Prihyugiarto, I. 2005. Faktor-Faktor Yang Mempengaruhi SikapTerhadap Perilaku Seksual Pria Nikah Pada Remaja Di Indonesia: BKKBN.

5 http://mediacerebri.wordpress.com/2009/09/04/hukum-zina-menurut-pandangan-islam/

6 Sarwono W.S. 2003. Psikologi Remaja. Jakarta: Grafindo Persada

7 Stuart G.W. and Sundeen S.J. 1999. Principles and Practice of PsychiatricNursing. New York : Mosby Year Book, Inc.

$8 \mathrm{Mu}^{\prime}$ tadin Z. 2002. Pendidikan Seksual Pada Remaja. Available at : http//:www.epsikologi. com. Diakses tanggal 26 April 2008.

${ }^{9} \mathrm{http}: / /$ www.suara-islam.com/read4599-Waspadai-Seks-Bebas-di-Kalangan-Remaja-\%28Bag$1 \% 29 . \mathrm{html}$

${ }^{10}$ Suryoputro A., Nicholas J.F., Zahroh S., 2006. Faktor-faktor yang mempengaruhi Perilaku Seksual Remaja Di Jawa Tengah: Implikasinya Terhadap Kebijakan Dan 
Layanan Kesehatan Seksual Dan Reproduksi. Makara Kesehatan. vol.10. no.1 juni 2006: $29-40$

11 Syafrudin. 2008. Remaja Dan Hubungan Seksual Pranikah http://id.shvoong.com/ medicine-and-health/1799376-remaja-dan-hubunganseksual-pranikah/. Diakses pada tanggal 21 Januari 2009

12 Kinnaird. 2003. Keluarga Makin Baik Hubungan Orangtua-Remaja Makin Rendah Perilaku Seksual Pranikah http://www.kr.co.id/web/detail.php? sid=186024 \&actmenu = 45, Diakses pada Tanggal 6 Januari 2009.

${ }^{13}$ Rohmahwati D.A., Lutfiati, A., Sri M., 2008. Pengaruh Pergaulan Bebas DanVcd Porno Terhadap Perilaku Remaja Di Masyarakat. http://kbi.gemari.or.id/ beritadetail.php? id= 2569 Diakses Tanggal 29 November 2008

${ }^{14}$ Soetjiningsih.2006. Remaja Usia 15 - 18 Tahun Banyak Lakukan Perilaku Seksual Pranikah.http://www.ugm.ac.id/index.php?page=rilis\&artikel=1659. Diakses Tanggal 6 Januari 2009.

${ }^{15}$ Sarwono, WS. Op.cit

${ }^{16}$ Syahrin Harahap. 2005. Penegakan Moral Akademik di dalam dan diluar kampus. Jakarta: PT. RajaGrafindo Persada.

17 Ester Lince Napitupulu, " HIV/ AIDS Musuh dunia", Kompas, (1 September 2009),5

${ }^{18}$ Mutimmatul Saidah (2010) Integrasi Pendidikan Seks Dalam Kurikulum Pendidikan Agama Islam (Penelitian Pengembangan bagi Siswa SMA di Surabaya) Disertasi : IAIN Sunan Ampel Surabaya.

${ }^{19}$ BKKBN, "Penggunan alat Kontrasepsi Pada Remaja", dalam http://www.aids.ina. org/modules.php?name=News\&file=article\&sid=222 (15 September 2005)

${ }^{20}$ Direktorat Remaja dan Perlindungan Hak-hak Reproduksi Badan Koordinasi Keluarga Berencana, Tanya-Jawab Kesehatan Reproduksi Remaja (Jakarta: Yayasan Mitra Inti, 2001), 23-25.

\section{DAFTAR PUSTAKA}

BKKBN. 2005. "Penggunan alat Kontrasepsi Pada Remaja", dalam http:/ / www.aids.ina. org/modules.php?name=News\&file=article \&sid =222 (15 September 2005)

\section{Buku Panduan dan Informasi Akademik 2008-2009 UIN Suska Riau}

Direktorat Remaja dan Perlindungan Hak-hak Reproduksi Badan Koordinasi Keluarga Berencana, Tanya-Jawab Kesehatan Reproduksi Remaja. Jakarta: Yayasan Mitra Inti, 2001. 23-25

Elizabeth B.Harlock. 1991. Psikologi Perkembangan (edisi kelima). Erlangga: Jakarta

Ester Lince Napitupulu. 2009. "HIV/AIDS Musuh dunia", Kompas, (1 September 2009),5

Harahap, Syahrin. 2005. Penegakan Moral Akademik di dalam dan diluar kampus. Jakarta: PT. RajaGrafindo Persada 
Irawati dan Prihyugiarto, I. 2005. Faktor-Faktor Yang Mempengaruhi SikapTerhadap Perilaku Seksual Pria Nikah Pada Remaja Di Indonesia: BKKBN

Kinnaird. 2003. Keluarga Makin Baik Hubungan Orangtua-Remaja Makin Perilaku Seksual Pranikah http://www.kr.co.id/web/detail.php? sid=186024 \&actmenu = 45, Diakses pada Tanggal 6 Januari 2009

Mu'tadin Z. 2002. Pendidikan Seksual Pada Remaja. Available at :http//:www.epsikologi.com. Diakses tanggal 26 April 2008

Mutimmatul Saidah. 2010. Integrasi Pendidikan Seks Dalam Kurikulum Pendidikan Agama Islam (Penelitian Pengembangan bagi Siswa SMA di Surabaya) Disertasi : IAIN Sunan Ampel Surabaya

Rohmahwati D.A., Lutfiati, A., Sri M. 2008. Pengaruh Pergaulan Bebas DanVcd Porno Terhadap Perilaku Remaja Di Masyarakat. http://kbi.gemari.or.id/ beritadetail.php? id= 2569 Diakses Tanggal 29 November 2008

Sarwono W.S. 2003. Psikologi Remaja. Jakarta: Grafindo Persada

Soetjiningsih. 2006. Remaja Usia 15 - 18 Tahun Banyak Lakukan Perilaku Seksual Pranikah. http://www.ugm.ac.id/index.php? page= rilis\&artikel=1659. Diakses Tanggal 6 Januari 2009

Stuart G.W. and Sundeen S.J. 1999. Principles and Practice of PsychiatricNursing. New York : Mosby Year Book, Inc.

Suryoputro A., Nicholas J.F., Zahroh S., 2006. Faktor-faktor yang mempengaruhi Perilaku Seksual Remaja Di Jawa Tengah: Implikasinya Terhadap Kebijakan Dan Layanan Kesehatan Seksual Dan Reproduksi. Makara Kesehatan. vol.10. no.1 juni 2006: 29-40

Syafrudin. 2008. Remaja Dan Hubungan Seksual Pranikah http://id.shvoong.com/ medicine-and-health/1799376-remajadan-hubunganseksual-pranikah/. Diakses pada tanggal 21 Januari 2009 